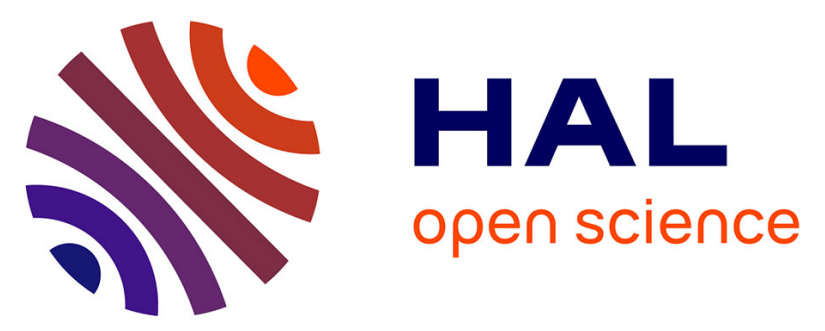

\title{
Workload, well-being and career satisfaction among French internal medicine physicians and residents in 2018
}

Fleur Cohen Aubart, Raphael Lhote, Olivier Steichen, Anaïs Roeser, Nguekap

Otriv, Hervé Levesque, Philippe Morlat, Zahir Amoura, Luc Mouthon

\section{To cite this version:}

Fleur Cohen Aubart, Raphael Lhote, Olivier Steichen, Anaïs Roeser, Nguekap Otriv, et al.. Workload, well-being and career satisfaction among French internal medicine physicians and residents in 2018. Postgraduate Medical Journal, 2019, 96 (1131), pp.21-27. 10.1136/postgradmedj-2019-136657 . hal02441750

\section{HAL Id: hal-02441750 https://hal.sorbonne-universite.fr/hal-02441750}

Submitted on 16 Jan 2020

HAL is a multi-disciplinary open access archive for the deposit and dissemination of scientific research documents, whether they are published or not. The documents may come from teaching and research institutions in France or abroad, or from public or private research centers.
L'archive ouverte pluridisciplinaire HAL, est destinée au dépôt et à la diffusion de documents scientifiques de niveau recherche, publiés ou non, émanant des établissements d'enseignement et de recherche français ou étrangers, des laboratoires publics ou privés. 
Workload, well-being and career satisfaction among French internal medicine physicians and residents in 2018

Running title: Careers in French internal medicine

Fleur Cohen Aubart ${ }^{1}, \mathrm{MD}, \mathrm{PhD}$, Raphael Lhote ${ }^{1}$, MD, Olivier Steichen ${ }^{2}$, MD, PhD, Anaïs Roeser $^{1,3}$, MD, Nguekap Otriv³ ${ }^{3}$ MD, Hervé Lévesque ${ }^{4}, \mathrm{MD}, \mathrm{PhD}$, Philippe Morlat ${ }^{5}, \mathrm{MD}$, PhD, Zahir Amoura1 ${ }^{1}$ MD, MSc, and Luc Mouthon ${ }^{6}, \mathrm{MD}, \mathrm{PhD}$

\section{Affiliations}

${ }^{1}$ Sorbonne Université, Assistance Publique-Hôpitaux de Paris, Hôpital de la PitiéSalpêtrière, Service de Médecine Interne 2, Centre National de Référence Maladies Systémiques Rares, 75013-Paris, France

${ }^{2}$ Sorbonne Université, Assistance Publique-Hôpitaux de Paris, Hôpital Tenon, Service de Médecine Interne, 75020-Paris, France

${ }^{3}$ Université Paris Descartes, Amicale des Jeunes Internistes, 75014-Paris, France

${ }^{4}$ Centre Hospitalier Universitaire de Rouen

${ }^{5}$ Centre Hospitalier Universitaire de Bordeaux

${ }^{6}$ Université Paris Descartes, Assistance Publique-Hôpitaux de Paris, Hôpital Cochin, Service de Médecine Interne, 75014-Paris, France

This work did not receive any financial support.

The authors declare no conflicts of interest.

Key words: well-being, career, internal medicine, residents, burnout 


\section{Correspondence to:}

Dr. Fleur Cohen Aubart, Service de Médecine Interne 2, Hôpital Pitié-Salpêtrière, 47-83

Boulevard de l’hôpital, 75651 Paris CEDEX 13

Phone +331421782 42; Fax +33142165804

fleur.cohen@psl.aphp.fr

Number of words in abstract: 247

Number of words in the whole text: 2232

Number of references: 18

Number of tables: 5

\section{Authors contributions}

F.C.-A., O.S., H.L., Ph.M., and L.M. designed the study.

F.C.-A., R.L., O.S., and L.M. collected the data.

F.C.A., R.L., and O.S. conducted the statistical analysis.

F.C.-A., R.L., O.S., A.R., N.O., Z.A., and L.M. analyzed and interpreted the data.

F.C.-A, O.S. and L.M. wrote the manuscript.

All authors critically reviewed and approved the final version of the manuscript.

\section{Bullet points}

1. In France, $66 \%$ of Internal Medicine physicians are satisfied with their work.

2. Factors associated with global satisfaction at work of French Internal medicine physicians are autonomy and meaningful work.

3. French internal medicine residents work more hours a week and have a worse global appreciation of their work than graduate physicians. 


\section{Abstract}

Objectives: To study the prevalence and risk factors associated with well-being and career satisfaction among French internal medicine physicians and residents.

Methods: A total of 1,689 French internal medicine physicians or trainees were surveyed to evaluate their workload, well-being and career satisfaction during February 2018.

Results: The response rate was $620 / 1,689$ (37\%). The mean age of the participants was 37 years $( \pm 12)$; $49 \%$ of the participants were female, $27 \%$ worked in the Paris area, $74 \%$ worked in a university hospital, and $49 \%$ were residents. Sixty-six percent of the responders were satisfied with their work, and $66 \%$ would choose the internal medicine specialty again. However, $71 \%$ of the responders worked more than 50 hours a week, 21\% worked more than 60 hours a week, and $70 \%$ believed that they did not have enough time for personal/family activities. Twenty-five percent of the responders had at least one sign of burnout (19\% of the physicians in practice and $32 \%$ of the residents). Compared with the graduate physicians in practice, the residents worked more hours a week, had more activities at night, spent more time on administrative tasks, had a worse global appreciation of their work and felt that their work was less meaningful. In multivariate analysis, the factors associated with global satisfaction at work were autonomy and meaningful work.

Conclusions: French internal medicine physicians have a high rate of career satisfaction. However, residents have a higher workload, less time for personal/family activities, and feel that their work is less meaningful. 
The "Société Nationale Française de Médecine Interne" (SNFMI) is the national French scientific society of internal medicine, created in 1978 under the initiative of Claude Laroche and Pierre Godeau. In 2017, the SNFMI was composed of various members with a common interest in internal medicine. SNFMI publishes a monthly scientific journal, "La Revue de Médecine Interne”, organizes 2 national meetings a year, and works closely with the "Collège des Enseignants de Médecine Interne" (CEMI), comprised of internal medicine teachers, for training of medical students, residents and postdoctoral physicians. The SNFMI is composed of various physicians, residents, fellows and graduates practicing in university, general or military hospitals. They have teaching and research activities, and they have varied types of medical practice. The majority of SNFMI members are hospital-based physicians working in university or non-university hospitals. Due to the acceleration of the transformation of medical practice, the increased difficulties in obtaining grants to support research, and the implementation of the reform of the third cycle of medical studies in France, internal medicine physicians, as other French specialists, experience professional burnout. Burnout includes a lack of professional well-being and poor work-life balance and is characterized by 3 major domains: emotional exhaustion, depersonalization and a sense of low accomplishment [1]. In the United States (US), up to $50 \%$ of physicians have at least one symptom of burnout [2]. Burnout is distinct from depression, fatigue, or occupational stress. When occurring in physicians, burnout is associated with lower scores of patient satisfaction and health care quality, more conflicts between work and home life, more depression, and more suicides [3]. Many factors are associated with burnout, such as workload, excessive clerical tasks, and issues with work-life integration. The rate of burnout seems to be higher among residents than among those in practice [4]. Resident burnout has 
been related to medical errors. Unlike burnout, career satisfaction could increase the desirability of being a physician.

The SNFMI surveyed French members and internal medicine residents to explore the question of workload, well-being and career satisfaction of internal medicine physicians in France. Here, we report the results of this national survey.

\section{Methods}

\section{Study population}

The population of interest included internal medicine physicians and trainees who were current members of the SNFMI and had provided an email address $(n=899)$ or were third-cycle medical students enrolled in the Diplôme d'Etudes Spécialisées (DES) of internal medicine at French universities $(\mathrm{n}=790)$. Thus, the eligible population consisted of 1,689 physicians or trainees. These members were e-mailed a link for the online survey in February 2018, followed by 2 additional e-mail reminders. The online survey was closed 30 days after the first e-mail was sent. All communications and data collection were conducted on behalf of the SNFMI and the CEMI, and the answers were anonymous. The data from those who completed the survey were analyzed in MayAugust 2018.

\section{Endpoints}

The survey consisted of 29 questions covering personal and professional characteristics $(n=8)$, workload $(n=8)$, well-being, and career satisfaction $(n=13)$. A free text area was also available at the end of the study. Residents had 3 additional questions regarding professional characteristics and training. Workload was evaluated with the number of professional working hours each week, night activity, number of outpatients seen each 
week and number of weekend rounds a year. Quality of life and overall fatigue were evaluated on a numerical scale (from 1 to 10). Career satisfaction was evaluated by exploring the desire to become a physician and an internal medicine physician again and the overall satisfaction of the job. Autonomy and meaning in the work were also evaluated, as well as the number of clerical tasks and effective support staff. Finally, burnout was evaluated with a self-reported assessment, and we explored the 3 dimensions of burnout with the Copenhagen Burnout Inventory (CBI) using 6 questions about personal burnout, 7 questions about work-related burnout and 3 questions in relation to patients. Each question was evaluated on a 5-point Likert scale. The 2 highest points were considered to be a high score, the middle point was considered to be an intermediate score, and the 2 lowest points were considered to be a low score.

\section{Statistical analyses}

Descriptive statistics were used to characterize the population. Quantitative variables are reported as the mean (standard deviation - SD) and were compared using a twotailed Student's t-test. Categorical variables are reported as counts (percentages) and were compared using Fisher's exact test or a trend $\mathrm{Chi}^{2}$ test, as appropriate. Logistic regression models were used to identify factors associated with well-being and career satisfaction. All predictors significantly associated with endpoints in the univariate models were entered in a multivariate model. All tests were two-sided, and a p-value < 0.05 was considered statistically significant. R software version 3.0.2 (www.rproject.org/foundation/) was used for statistical analyses.

\section{Standard protocol approvals and consents}


Completing the survey implied consent to participate in the study. The study was reviewed and approved by the Commission Nationale Informatique et Libertés (CNIL).

\section{Results}

\section{Personal and practice characteristics}

Of the 1,689 internal medicine physicians or third-cycle students surveyed, 620 (37\%) agreed to participate in the study. Their demographic, personal and practice characteristics are detailed in Table 1. Among the responders, the mean age was 37 (SD 12), and 302 (49\%) were women. Compared to the total population of the SNFMI members, the responders were younger (44\% were less than 30-years-old, compared to $24 \%$ in the whole population of the SNFMI) and were more frequently women (49\% versus $41 \%$ in the whole population). The population consisted of 314 residents (51\%) and 306 internal medicine physicians in practice who did not differ by sex. The residents were younger than the physicians in practice. The main geographic region of exercise was Ile de France, which includes Paris and its suburban areas, although all French regions were represented. The graduated responders practiced internal medicine for 010 years in $39 \%$ of cases, $11-20$ years in $29 \%$ of cases and more than 21 years in $31 \%$ of cases. The residents were representative of the whole resident population, with $13-21 \%$ for each year of training. The residents practiced more frequently in university hospitals than the physicians in practice (84\% versus 63\%). Twenty-one percent of the responders worked in a general hospital, and $2.5 \%$ of the responders had a militarybased practice.

\section{Workload}


The medical workload of internal medicine physicians and residents in France is detailed in Table 2. Sixty-one percent of the physicians worked more than 50 hours a week, and 21\% worked more than 60 hours a week. The workload of the residents was significantly higher than that of the physicians in practice. The majority of the physicians worked less than 5 hours a week during their time at home. The residents devoted more time to clinical practice, whereas the physicians in practice divided their time between clinical practice, teaching and research. Compared to the physicians in practice, the residents had more activities at night and a higher number of weekends when they rounded in the hospital per year.

\section{Well-being and career satisfaction}

The well-being and career satisfaction of internal medicine physicians and residents are detailed in Tables 2 and 3. The burnout manifestations are reported in Table 4. The factors associated with well-being and career satisfaction in univariate and multivariate analyses are reported in Table $\mathbf{5 .}$

Concerning career satisfaction, $61 \%$ of the internal medicine physicians would choose to become a physician again, and $65 \%$ would choose to become an internal medicine physician again. Career satisfaction scores differed between the residents and physicians in practice, with fewer residents indicating that they would become both a physician $(\mathrm{p}<0.001)$ and an internal medicine physician $(\mathrm{p}=0.048)$ again. In multivariate analysis, the factors associated with career satisfaction were autonomy in the job, reporting that the job was meaningful, and an age $>60$ years. A high percentage $(>40 \%)$ of immunology in their practice and a reasonable number of clerical tasks were also associated with choosing to become an internal medicine physician again. 
Overall, $25 \%$ of the internal medicine physicians had at least one symptom of burnout, although only $14 \%$ self-reported an experience of burnout. Compared to the physicians in practice, the residents had higher rates of all symptoms of burnout, except for frustration at work. They reported a lower rate of self-reported effective work for patients ( $43 \%$ versus $66 \%$ for the physicians in practice, $\mathrm{p}<0.001$ ), and a lower rate of feeling that the time spent on clerical tasks directly connected to patient care was reasonable (23\% versus $37 \%$ for the physicians in practice, $p<0.001)$. Twenty-two percent of the physicians reported having too little effective support staff assisting them in their work.

\section{Discussion}

In this study, we identified several important factors concerning workload, well-being and career satisfaction of the internal medicine physician population in France: i) $71 \%$ of the physicians worked more than 50 hours a week, and the residents had a higher workload than the physicians in practice; ii) $70 \%$ of the physicians believed that they did not have enough time for personal/family life; iii) the global level of career satisfaction was high, as $82 \%$ of the physicians would become physicians again and as $86 \%$ would become internal medicine physicians again; iv) the residents had lower scores of career satisfaction and higher rates of burnout.

Burnout risk is a situationally specific risk. Some domains have been identified as increasing burnout risk, including workload, community, fairness and values. Burnout in medical practice is common in medical and surgical specialties but varies by specialty. The workload was high for all categories of physicians and was higher for the residents than the physicians in practice. In France, the legal maximal work week is 48 working hours. In this study, we found that almost $3 / 4$ of physicians reported working more than 
50 hours, and the hours of work at home were not included. Workload has been associated with burnout in many specialties, although the time spent in clinical practice is usually associated with a lower rate of burnout. In a previous study of internal medicine trainees in the US, the burnout rate dropped as the workload was reduced from 2004 through 2012 [5]. In the recent iCompare study [6], 63 internal medicine residency programs were randomly assigned to employ classical duty-hours or flexibility policies. The results did not demonstrate differences in the time spent in clinical practice. Interestingly, the interns were less satisfied with the flexible programs, although the seniors were more satisfied. This illustrates that workload may not be the most important factor in career dissatisfaction.

Indeed, the time spent on clerical tasks is frequently associated with career dissatisfaction. In our study, we found that $70 \%$ of the physicians reported that the time spent on clerical tasks was too high, increasing to $90 \%$ for clerical tasks that were not directly related to patient care. On the other hand, $22 \%$ of the physicians stated that they had insufficient or ineffective support from their staff.

We found that $25 \%$ of the internal medicine physicians had at least one symptom of burnout. This rate is lower than that of many US studies, including those among oncologists or neurologists [7]. In France, the rate of burnout was estimated to be $62 \%$ among anesthesiology nurses and physicians [8], 56\% among pharmacists [9] 71\% of European young oncologists [10], which are specialties that are particularly at risk for burnout. Among physicians, those who are at the front lines of care access are more prone to burnout, such as family medicine, general internal medicine, and emergency medicine [11]. In France, internal medicine encompasses general internal medicine and immunology. Physicians who spend over $40 \%$ of their time caring for patients with immunological or inflammatory diseases seemed to have higher work satisfaction, 
probably because they were not at the front lines of care. Burnout symptoms increased from $40 \%$ to over $50 \%$ in internal medicine subspecialists in US from 2011 to 2014 , with significant disparities among medical specialties [2]. Although recent data were obtained among pediatric or emergency medicine physicians, data about career satisfaction and burnout are limited among medical subspecialties [12]. Among nephrologists or cardiologists, up to $50 \%$ of physician may report at least one symptom of burnout [13 14].

Interestingly, age $>60$ years was associated with greater career satisfaction, whereas younger internal medicine physicians exhibited lower rates of feeling that their work was meaningful and of global satisfaction. Gender was not associated with any differences in the evaluated endpoints. In other studies, the middle of the career appeared to be a challenging time for physicians [15]. We found a lower rate of career satisfaction in trainees, and specific interventions must be devised to promote career satisfaction and retention.

This study has some limitations. Although we obtained a high rate of participation, equivalent to other similar surveys [16 17], we cannot exclude important biases in the population of the responders compared to the nonresponders. We used the CBI questionnaire to evaluate the rates of burnout, although other studies used the Maslach Burnout Inventory. These 2 questionnaires are effective in detecting burnout but have not been directly compared [18]. This may have contributed to the lower rate of burnout observed in this study compared to that of US physicians.

We found that an excessive workload, a high number of clerical tasks, and a loss of autonomy were associated with less career satisfaction. The internal medicine residents had a high rate of burnout symptoms; thus, urgent measures need to be taken to 
promote career satisfaction, reduce burnout and prevent career resignation among younger internists. 
Table 1. Personal and practice characteristics of internal medicine physicians in

France.

\begin{tabular}{|c|c|c|c|c|}
\hline & $\begin{array}{c}\text { All } \\
(n=620)\end{array}$ & $\begin{array}{c}\text { Nonresidents } \\
(\mathrm{n}=306)\end{array}$ & $\begin{array}{c}\text { Residents } \\
(\mathrm{n}=314)\end{array}$ & $\mathrm{P}$ \\
\hline \multicolumn{5}{|l|}{ Age (years) } \\
\hline Mean (SD) & $37(12)$ & $46(11)$ & $28(2)$ & $<0.001$ \\
\hline$<30$ & $275(44 \%)$ & $4(1.5 \%)$ & $271(86 \%)$ & \\
\hline $30-45$ & 179 (29\%) & $151(49 \%)$ & $28(9 \%)$ & $<0.0001$ \\
\hline $45-60$ & 115 (19\%) & $115(38 \%)$ & 0 & \\
\hline$>60$ & $32(5 \%)$ & $32(10 \%)$ & 0 & \\
\hline Missing data & $19(3 \%)$ & $4(1.5 \%)$ & $15(5 \%)$ & \\
\hline \multicolumn{5}{|l|}{ Sex } \\
\hline Female/Male & $302 / 315$ & $142 / 163$ & $160 / 152$ & 0.3 \\
\hline Missing data & $3(0.5 \%)$ & $1(0.3 \%)$ & $2(0.6 \%)$ & \\
\hline $\begin{array}{l}\text { Geographic region of exerci } \\
\text { Ile de France } \\
\text { Auvergne Rhône Alpes } \\
\text { Grand Est } \\
\text { Nouvelle Aquitaine } \\
\text { PACA } \\
\text { Occitanie } \\
\text { Normandie } \\
\text { Hauts de France } \\
\text { Pays de Loire } \\
\text { Bourgogne Franche Comté } \\
\text { Centre Val de Loire } \\
\text { Bretagne } \\
\text { DOM-TOM } \\
\text { Corse } \\
\text { Missing data }\end{array}$ & $\begin{array}{c}166(27 \%) \\
66(10.5 \%) \\
60(9.5 \%) \\
46(7.5 \%) \\
44(7 \%) \\
38(6 \%) \\
37(6 \%) \\
31(5 \%) \\
31(5 \%) \\
28(4.5 \%) \\
26(4 \%) \\
25(4 \%) \\
9(1.5 \%) \\
1(0.5 \%) \\
12(2 \%)\end{array}$ & $\begin{array}{c}90(29 \%) \\
37(12 \%) \\
28(9 \%) \\
23(8 \%) \\
19(6 \%) \\
20(6.5 \%) \\
18(6 \%) \\
11(3.5 \%) \\
14(4.5 \%) \\
15(5 \%) \\
8(2.5 \%) \\
11(4.5 \%) \\
5(1.5 \%) \\
0(0 \%) \\
7(2 \%)\end{array}$ & $\begin{array}{c}76(24.5 \%) \\
29(9 \%) \\
32(10 \%) \\
23(7.5 \%) \\
25(8 \%) \\
18(5.5 \%) \\
19(6 \%) \\
20(6.5 \%) \\
17(5.5 \%) \\
13(4 \%) \\
18(5.5 \%) \\
14(4.5 \%) \\
4(1.5 \%) \\
1(0.5 \%) \\
5(1.5 \%)\end{array}$ & 0.6 \\
\hline \multicolumn{5}{|l|}{$\begin{array}{l}\text { Time since graduation } \\
\text { (years) }\end{array}$} \\
\hline $0-5$ & - & $70(23 \%)$ & - & - \\
\hline $6-10$ & - & $50(16 \%)$ & - & - \\
\hline $11-20$ & - & $88(29 \%)$ & - & - \\
\hline $11-30$ & - & $62(20 \%)$ & - & - \\
\hline $30-40$ & - & $30(10 \%)$ & - & - \\
\hline
\end{tabular}




\begin{tabular}{|c|c|c|c|c|}
\hline$>40$ & - & $3(1 \%)$ & - & - \\
\hline Missing data & - & $3(1 \%)$ & - & - \\
\hline \multicolumn{5}{|l|}{ Year of residency } \\
\hline $1^{\text {st }}$ year & - & - & $42(13 \%)$ & - \\
\hline $2^{\text {nd }}$ year & - & - & $64(20 \%)$ & - \\
\hline $3^{\text {rd }}$ year & - & - & $65(21 \%)$ & - \\
\hline $4^{\text {th }}$ year & - & - & $60(19 \%)$ & - \\
\hline $5^{\text {th }}$ year & - & - & $59(19 \%)$ & - \\
\hline Others & - & - & $24(8 \%)$ & - \\
\hline Missing data & - & - & 0 & - \\
\hline \multicolumn{5}{|l|}{ Type of practice } \\
\hline University hospital & $458(74 \%)$ & $193(63 \%)$ & $265(84 \%)$ & \multirow{6}{*}{$<0.001$} \\
\hline General hospital & $130(21 \%)$ & $91(30 \%)$ & $39(12.5 \%)$ & \\
\hline Private hospital & $10(1.5 \%)$ & $10(3 \%)$ & $0(0 \%)$ & \\
\hline Military hospital & $16(2.5 \%)$ & $7(2 \%)$ & $9(3 \%)$ & \\
\hline Clinical practice & $5(1 \%)$ & $4(1 \%)$ & $1(0.5 \%)$ & \\
\hline Missing data & 1 & 1 & 0 & \\
\hline \multicolumn{5}{|l|}{ Physical activity } \\
\hline Never & $126(20 \%)$ & $59(19 \%)$ & $67(21 \%)$ & \multirow{4}{*}{0.022} \\
\hline At least once a month & $193(31 \%)$ & $79(26 \%)$ & $114(36.5 \%)$ & \\
\hline More than once a week & $298(48 \%)$ & $166(54 \%)$ & $132(42 \%)$ & \\
\hline Missing data & $3(0.5 \%)$ & $2(1 \%)$ & $1(0.5 \%)$ & \\
\hline
\end{tabular}


Table 2. Medical workload of internal medicine physicians in France.

\begin{tabular}{|c|c|c|c|c|}
\hline & $\begin{array}{c}\text { All } \\
(n=620)\end{array}$ & $\begin{array}{l}\text { Nonresidents } \\
\quad(n=306)\end{array}$ & $\begin{array}{l}\text { Residents } \\
(\mathrm{n}=314)\end{array}$ & $\mathrm{p}$ \\
\hline \multicolumn{5}{|l|}{ Hours / week } \\
\hline \multicolumn{5}{|l|}{ (in hospital) } \\
\hline 35 & $6(1 \%)$ & $5(2 \%)$ & $1(0.5 \%)$ & \multirow{8}{*}{$<0.0001$} \\
\hline $36-40$ & $9(1.5 \%)$ & $9(3 \%)$ & $0(0 \%)$ & \\
\hline $41-45$ & $45(7.5 \%)$ & $31(10 \%)$ & $14(4 \%)$ & \\
\hline $46-50$ & $108(17 \%)$ & $82(27 \%)$ & $26(8 \%)$ & \\
\hline $51-55$ & $161(26 \%)$ & $91(30 \%)$ & $70(22 \%)$ & \\
\hline $56-60$ & $152(24.5 \%)$ & 43 (14\%) & $109(35 \%)$ & \\
\hline$>60$ & $129(21 \%)$ & $38(12 \%)$ & $91(29 \%)$ & \\
\hline Missing data & $10(1.5 \%)$ & $7(2 \%)$ & $3(1 \%)$ & \\
\hline \multicolumn{5}{|l|}{$\begin{array}{l}\text { Hours / week } \\
\text { (home) }\end{array}$} \\
\hline $0-5$ & $356(57.5 \%)$ & $170(56 \%)$ & $186(59 \%)$ & \multirow{6}{*}{0.76} \\
\hline $6-10$ & 167 (27\%) & $81(26 \%)$ & $86(27 \%)$ & \\
\hline $11-15$ & $50(8 \%)$ & $25(8 \%)$ & $25(8 \%)$ & \\
\hline $16-20$ & $20(3 \%)$ & $11(4 \%)$ & $9(3 \%)$ & \\
\hline$>20$ & $12(2 \%)$ & $7(2 \%)$ & $5(2 \%)$ & \\
\hline Missing data & $15(2.5 \%)$ & $12(4 \%)$ & $3(1 \%)$ & \\
\hline \multicolumn{5}{|l|}{ Night activity } \\
\hline No & $280(45 \%)$ & $250(82 \%)$ & $30(10 \%)$ & \multirow{3}{*}{$<0.001$} \\
\hline Yes & $338(54.5 \%)$ & $56(18 \%)$ & $282(90 \%)$ & \\
\hline Missing data & $2(0.3 \%)$ & 0 & $2(0.6 \%)$ & \\
\hline Mean (per month) (SD) & $2.4(1.2)$ & $1.6(1)$ & $2.5(1.2)$ & $<0.001$ \\
\hline \multicolumn{5}{|c|}{$\begin{array}{l}\% \text { of time* devoted to clinical } \\
\text { practice }\end{array}$} \\
\hline$<50 \%$ & $329(53 \%)$ & $135(44 \%)$ & $194(62 \%)$ & \multirow{3}{*}{$<0.001$} \\
\hline $51-70 \%$ & $152(25 \%)$ & $94(31 \%)$ & $58(18 \%)$ & \\
\hline$>70 \%$ & $126(20 \%)$ & $71(23 \%)$ & $54(17 \%)$ & \\
\hline \multicolumn{5}{|l|}{$\begin{array}{l}\% \text { of time* devoted to } \\
\text { research }\end{array}$} \\
\hline$<10 \%$ & $441(71 \%)$ & $202(68 \%)$ & $239(79 \%)$ & \multirow{3}{*}{$<0.001$} \\
\hline $10-20 \%$ & $144(23 \%)$ & $91(30 \%)$ & $53(17 \%)$ & \\
\hline$>30 \%$ & $18(3 \%)$ & $6(2 \%)$ & $12(4 \%)$ & \\
\hline \multicolumn{5}{|l|}{$\begin{array}{l}\% \text { of time devoted to } \\
\text { teaching }\end{array}$} \\
\hline$<10 \%$ & $414(67 \%)$ & $165(54 \%)$ & $249(79 \%)$ & \\
\hline $11-30 \%$ & $169(27 \%)$ & $119(39 \%)$ & $50(16 \%)$ & $<0.001$ \\
\hline
\end{tabular}




\begin{tabular}{|c|c|c|c|c|}
\hline$>30 \%$ & $20(3 \%)$ & $15(5 \%)$ & $5(2 \%)$ & \\
\hline Missing data & $17(3 \%)$ & $7(2 \%)$ & $10(3 \%)$ & \\
\hline \multicolumn{4}{|c|}{$\begin{array}{l}\% \text { of time* devoted to } \\
\text { administration }\end{array}$} & \multirow{5}{*}{$<0.001$} \\
\hline$<30 \%$ & 324 (52\%) & $205(67 \%)$ & $119(38 \%)$ & \\
\hline $31-50 \%$ & 191 (31\%) & $83(27 \%)$ & 108 (34\%) & \\
\hline$>50 \%$ & $100(16 \%)$ & $17(6 \%)$ & $83(36 \%)$ & \\
\hline Missing data & $5(1)$ & $1(0 \%)$ & $4(1 \%)$ & \\
\hline $\begin{array}{l}\% \text { of medical a } \\
\text { immunology }\end{array}$ & & & & \multirow{5}{*}{0.008} \\
\hline $0-40$ & 488 (79\%) & $232(76 \%)$ & $256(81.5 \%)$ & \\
\hline $41-60$ & $76(12 \%)$ & $42(13.5 \%)$ & $34(11 \%)$ & \\
\hline $61-100$ & $45(7 \%)$ & $30(10 \%)$ & $15(4.5 \%)$ & \\
\hline Missing data & $11(2 \%)$ & $2(0.5 \%)$ & $9(3 \%)$ & \\
\hline \multicolumn{4}{|c|}{$\begin{array}{l}\% \text { of medical activities in } \\
\text { general medicine }\end{array}$} & \multirow{5}{*}{0.08} \\
\hline $0-40$ & $160(26 \%)$ & $85(28 \%)$ & $75(24 \%)$ & \\
\hline $41-60$ & 169 (27\%) & $91(29.5 \%)$ & $78(25 \%)$ & \\
\hline $61-100$ & $280(45 \%)$ & $127(41.5 \%)$ & $153(48.5 \%)$ & \\
\hline Missing data & $11(2 \%)$ & $3(1 \%)$ & $8(2.5 \%)$ & \\
\hline \multicolumn{4}{|c|}{$\begin{array}{l}\text { Number of outpatients seen } \\
\text { per week }\end{array}$} & \multirow{9}{*}{$<0.001$} \\
\hline None & 237 (38\%) & $7(2 \%)$ & $230(73 \%)$ & \\
\hline $1-10$ & $110(18 \%)$ & $60(29.5 \%)$ & $50(16 \%)$ & \\
\hline $11-20$ & $136(22 \%)$ & $122(40 \%)$ & $14(4.5 \%)$ & \\
\hline $21-30$ & $73(12 \%)$ & $64(21 \%)$ & $9(3 \%)$ & \\
\hline $31-40$ & $29(4.5 \%)$ & $28(9 \%)$ & $1(0.5 \%)$ & \\
\hline $41-50$ & $12(2 \%)$ & $10(3.5 \%)$ & $2(0.5 \%)$ & \\
\hline More than 50 & $16(2.5 \%)$ & $15(5 \%)$ & $1(0.5 \%)$ & \\
\hline Missing data & $7(1 \%)$ & $0(0 \%)$ & $7(2 \%)$ & \\
\hline \multicolumn{4}{|c|}{$\begin{array}{l}\text { Number of inpatient rounds } \\
\text { per week }\end{array}$} & \multirow{5}{*}{$<0.001$} \\
\hline None & $28(4.5 \%)$ & 17 (5.5\%) & $11(3.5 \%)$ & \\
\hline $1-3$ & $274(44 \%)$ & $203(66.5 \%)$ & $71(22.5 \%)$ & \\
\hline More than 3 & $306(49.5 \%)$ & $83(27 \%)$ & $223(71 \%)$ & \\
\hline Missing data & $12(2 \%)$ & $3(1 \%)$ & $9(3 \%)$ & \\
\hline \multicolumn{4}{|c|}{$\begin{array}{l}\text { Number of weekends } \\
\text { rounded in hospital per year } \\
\text { None }\end{array}$} & \multirow{5}{*}{$<0.001$} \\
\hline $1-5$ & $41(6.5 \%)$ & $20(6.5 \%)$ & $21(7 \%)$ & \\
\hline $6-10$ & $53(8.5 \%)$ & $37(12 \%)$ & $16(5 \%)$ & \\
\hline $11-15$ & 178 (29\%) & $114(37 \%)$ & $64(20 \%)$ & \\
\hline More than 15 & 224 (36\%) & $103(34 \%)$ & $121(39 \%)$ & \\
\hline
\end{tabular}




\begin{tabular}{lccc}
\hline Missing data & $119(19 \%)$ & $31(10 \%)$ & $88(28 \%)$ \\
& $5(1 \%)$ & $1(0.5 \%)$ & $4(1 \%)$
\end{tabular}

* among professional time 
Table 3. Well-being and career satisfaction among internal medicine physicians in France.

\begin{tabular}{|c|c|c|c|c|}
\hline & $\begin{array}{c}\text { All } \\
(n=620)\end{array}$ & $\begin{array}{l}\text { Nonresidents } \\
\quad(n=306)\end{array}$ & $\begin{array}{l}\text { Residents } \\
(\mathrm{n}=314)\end{array}$ & $\mathrm{p}$ \\
\hline \multicolumn{5}{|c|}{$\begin{array}{l}\text { Quality of life during the past } \\
\text { week (1-10 scale) }\end{array}$} \\
\hline Mean (SD) & $5.9(1.9)$ & $6.2(1.8)$ & $5.7(1.9)$ & 0.003 \\
\hline \multicolumn{5}{|c|}{$\begin{array}{l}\text { Overall fatigue during the } \\
\text { past week (1-10 scale) }\end{array}$} \\
\hline Mean (SD) & $6.4(2.0)$ & $6.1(2.1)$ & $6.7(1.8)$ & $<0.001$ \\
\hline \multicolumn{5}{|c|}{ Global satisfaction of work } \\
\hline High & $409(66 \%)$ & $215(70.5 \%)$ & $194(62 \%)$ & \multirow{4}{*}{0.054} \\
\hline Intermediate & $118(19 \%)$ & $50(16 \%)$ & $68(22 \%)$ & \\
\hline Low & $86(14 \%)$ & $38(12.5 \%)$ & $48(15 \%)$ & \\
\hline Missing data & $7(1 \%)$ & $3(1 \%)$ & $4(1 \%)$ & \\
\hline \multicolumn{5}{|c|}{$\begin{array}{l}\text { Career choice: would become } \\
\text { again a physician }\end{array}$} \\
\hline High & $380(61 \%)$ & $216(71 \%)$ & $164(52 \%)$ & \multirow{4}{*}{$<0.0001$} \\
\hline Intermediate & $133(21.5 \%)$ & $57(19 \%)$ & $76(24 \%)$ & \\
\hline Low & $106(17 \%)$ & $32(10 \%)$ & $74(24 \%)$ & \\
\hline Missing data & $1(0.1 \%)$ & $1(0.3 \%)$ & 0 & \\
\hline \multicolumn{5}{|c|}{$\begin{array}{l}\text { Career choice: would become } \\
\text { again internal medicine } \\
\text { physician }\end{array}$} \\
\hline High & $400(65.5 \%)$ & $212(69 \%)$ & $188(60 \%)$ & \multirow{4}{*}{0.045} \\
\hline Intermediate & $128(21 \%)$ & $53(17 \%)$ & $75(24 \%)$ & \\
\hline Low & $89(14 \%)$ & $40(13 \%)$ & $49(16 \%)$ & \\
\hline Missing data & $3(0.5 \%)$ & $1(0.3 \%)$ & $2(0.5 \%)$ & \\
\hline \multicolumn{5}{|c|}{ Conflict with a colleague } \\
\hline Yes & $69(11 \%)$ & $37(12 \%)$ & $32(10 \%)$ & \multirow{2}{*}{0.5} \\
\hline No & 551 (89\%) & $269(88 \%)$ & $282(90 \%)$ & \\
\hline Missing data & 0 & 0 & 0 & \\
\hline \multicolumn{5}{|c|}{$\begin{array}{l}\text { Personal life satisfaction: } \\
\text { having enough time for } \\
\text { personal/family activities }\end{array}$} \\
\hline High & $133(21.5 \%)$ & $88(29 \%)$ & 45 (12\%) & \multirow{4}{*}{$<0.0001$} \\
\hline Intermediate & $53(8.5 \%)$ & $31(10 \%)$ & $22(7 \%)$ & \\
\hline Low & $432(70 \%)$ & $186(61 \%)$ & $246(78 \%)$ & \\
\hline Missing data & $2(0.3 \%)$ & $1(0.3 \%)$ & $1(0.3 \%)$ & \\
\hline
\end{tabular}

Career satisfaction: having

significant autonomy in 


\begin{tabular}{lrrrr}
\hline $\begin{array}{l}\text { determining how I do my job, } \\
\text { agree (\%) }\end{array}$ & $349(56 \%)$ & $208(68 \%)$ & $141(45 \%)$ & $<0.001$ \\
\hline $\begin{array}{l}\text { Career satisfaction: the work } \\
\begin{array}{l}\text { I do is meaningful to me, } \\
\text { agree (\%) }\end{array}\end{array}$ & & & \\
\hline
\end{tabular}


Table 4. Burnout in internal medicine physicians in France.

\begin{tabular}{|c|c|c|c|c|}
\hline & $\begin{array}{c}\text { All } \\
(\mathrm{n}=620)\end{array}$ & $\begin{array}{c}\text { Nonresidents } \\
(\mathrm{n}=306)\end{array}$ & $\begin{array}{l}\text { Residents } \\
(\mathrm{n}=314)\end{array}$ & $\mathrm{p}$ \\
\hline \multicolumn{5}{|l|}{ Self-reported burnout } \\
\hline $\mathrm{n}(\%)$ & $88(14 \%)$ & $47(15 \%)$ & $41(13 \%)$ & 0.4 \\
\hline $\begin{array}{l}\text { At least one symptom of } \\
\text { burnout, } n(\%)\end{array}$ & $157(25 \%)$ & $57(19 \%)$ & $100(32 \%)$ & $<0.001$ \\
\hline \multicolumn{5}{|l|}{$\begin{array}{l}\text { Fatigue evaluation (high } \\
\text { score), n (\%) }\end{array}$} \\
\hline Fatigue & $538(87 \%)$ & $235(77 \%)$ & $303(96.5 \%)$ & $<0.001$ \\
\hline Physical fatigue & $457(74 \%)$ & $204(67 \%)$ & $253(81 \%)$ & $<0.001$ \\
\hline Emotional fatigue & $395(64 \%)$ & $165(54 \%)$ & $230(73 \%)$ & $<0.001$ \\
\hline Susceptibility to disease & $105(17 \%)$ & $31(10 \%)$ & $74(24 \%)$ & $<0.001$ \\
\hline \multicolumn{5}{|l|}{ Frustration at work } \\
\hline High & $181(29 \%)$ & $86(28 \%)$ & $95(30 \%)$ & \\
\hline Intermediate & $143(23 \%)$ & $63(21 \%)$ & $80(25 \%)$ & 0.168 \\
\hline Low & $287(46.5 \%)$ & $153(50 \%)$ & $134(43 \%)$ & \\
\hline Missing & $9(1.5 \%)$ & $4(1 \%)$ & $5(2 \%)$ & \\
\hline \multicolumn{5}{|l|}{$\begin{array}{l}\text { Depersonalization (high } \\
\text { score), n (\%) }\end{array}$} \\
\hline $\begin{array}{l}\text { Considering patients as } \\
\text { objects }\end{array}$ & $78(13 \%)$ & $23(7.5 \%)$ & $55(17.5 \%)$ & $<0.001$ \\
\hline Understanding patients & $411(66 \%)$ & $216(71 \%)$ & $195(62 \%)$ & 0.03 \\
\hline \multicolumn{4}{|l|}{ The work I do is effective for } & $<0.001$ \\
\hline \multicolumn{5}{|l|}{ Clerical tasks } \\
\hline $\begin{array}{l}\text { The amount of time I spend } \\
\text { on clerical tasks directly } \\
\text { related to patient care is } \\
\text { reasonable, } n(\%) \text { agree }\end{array}$ & $185(30 \%)$ & $113(37 \%)$ & $72(23 \%)$ & $<0.001$ \\
\hline $\begin{array}{l}\text { The amount of time I spend } \\
\text { on clerical tasks not directly } \\
\text { related to patient care is } \\
\text { reasonable, } \mathrm{n}(\%) \text { agree }\end{array}$ & $82(13 \%)$ & $41(13.5 \%)$ & $41(13 \%)$ & 0.1 \\
\hline \multicolumn{5}{|l|}{ Support staff } \\
\hline $\begin{array}{l}\text { Too little effective support } \\
\text { staff assisting me in my work, } \\
\mathrm{n}(\%)\end{array}$ & $139(22 \%)$ & $66(21.5 \%)$ & $73(23 \%)$ & 0.7 \\
\hline
\end{tabular}


Table 5. Factors associated with well-being and career satisfaction in univariate and multivariate analyses.

\begin{tabular}{|c|c|c|c|c|}
\hline & OR (univariate) & $\mathrm{p}$ & OR (multivariate) & $\mathrm{p}$ \\
\hline \multicolumn{5}{|l|}{$\begin{array}{l}\text { Factors associated with } \\
\text { satisfaction at work }\end{array}$} \\
\hline Autonomy in my job & $4(2.8-5.7)$ & $<0.001$ & $2.7(1.8-4.3)$ & $<0.001$ \\
\hline Meaningful work & $15.3(9.4-25.9)$ & $<0.001$ & $10.8(6.3-19.3)$ & $<0.001$ \\
\hline $\begin{array}{l}\text { Reasonable amount of clerical } \\
\text { tasks }\end{array}$ & $2.4[1.6-3.6]$ & $<0.001$ & $1.5(0.9-2.5)$ & 0.1 \\
\hline Effective support staff & $1.8(1.3-2.6)$ & $<0.001$ & $1.1(0.7-1.7)$ & 0.6 \\
\hline Hours worked a week $(>60)$ & $0.5(0.4-0.8)$ & 0.003 & $0.7(0.4-1.1)$ & 0.1 \\
\hline General hospital & $1.1(0.7-1.6)$ & 0.7 & - & - \\
\hline$>70 \%$ time clinical practice & $1.7(1.1-2.7)$ & 0.02 & $1.5(0.9-2.7)$ & 0.2 \\
\hline$>50 \%$ time administrative tasks & $0.6(0.4-0.9)$ & 0.01 & $0.9(0.5-1.7)$ & 0.8 \\
\hline More than $40 \%$ immunology & $1.1(0.7-1.7)$ & 0.7 & - & - \\
\hline Residents & $0.7(0.5-0.96)$ & 0.03 & $1.3(0.8-2.1)$ & 0.3 \\
\hline Age $(>60)$ & $2.7(1.1-8.2)$ & 0.04 & $1.9(0.6-7.1)$ & 0.3 \\
\hline Age $(<30)$ & $0.8(0.6-1.1)$ & 0.2 & - & - \\
\hline Sex (female) & $0.9(0.6-1.2)$ & 0.4 & - & - \\
\hline
\end{tabular}

Factors associated with being a physician again

Autonomy in my job

$\begin{array}{llcc}1.9(1.4-2.7) & <0.001 & 1.3(0.9-1.9) & 0.1 \\ 2.5(1.6-3.7) & <0.001 & 1.7(1.1-2.7) & 0.02\end{array}$

Meaningful work

Reasonable amount of clerical

tasks

$1.8(1.2-2.6)$

0.003

$1.3(0.9-2.0)$

0.2

Effective support staff

$1.2(0.9-1.7)$

0.2

Hours worked a week ( $>60)$

$0.5(0.3-0.7)$

$<0.001$

$0.6(0.4-0.98)$

0.04

$1.2(0.8-1.9)$

0.3

$>70 \%$ time clinical practice

$1.6(1.1-2.5)$

0.02

$0.5(0.3-0.7)$

$<0.001$

$1.4(0.9-2.1)$

0.1

More than 40\% immunology

$0.5(0.3-0.6)$

$<0.001$

0.5 (0.4-0.7)

$<0.001$

$1.3(0.8-2.0)$

0.3

Residents

$6.3(2.2-26.4)$

0.002

$0.8(0.5-1.4)$

0.5

Age (>60)

$1.0(0.7-1.4)$

0.9

Factors associated with being an internal medicine physician again 


\begin{tabular}{|c|c|c|c|c|}
\hline Autonomy in my job & $1.7(1.2-2.4)$ & 0.001 & $1.2(0.8-1.8)$ & 0.3 \\
\hline Meaningful work & $2.7(1.8-4.0)$ & $<0.001$ & $2(1.3-3.1)$ & 0.003 \\
\hline \multicolumn{4}{|l|}{ Reasonable amount of clerical } & 0.002 \\
\hline Effective support staff & $1.6(1.2-2.3)$ & 0.004 & $1.4(0.9-2)$ & 0.09 \\
\hline Hours worked a week $(>60)$ & $0.7(0.5-1.1)$ & 0.1 & - & - \\
\hline General hospital & $1.6(1.1-2.5)$ & 0.03 & $1.4(0.9-2.3)$ & 0.2 \\
\hline$>70 \%$ time clinical practice & $1.3(0.8-2.0)$ & 0.2 & - & - \\
\hline$>50 \%$ time administrative tasks & $0.7(0.4-1.0)$ & 0.07 & - & - \\
\hline More than $40 \%$ immunology & $1.7(1.1-2.6)$ & 0.03 & $1.7(1.04-2.7)$ & 0.03 \\
\hline Residents & $0.7(0.5-0.9)$ & 0.2 & - & - \\
\hline Age $>60$ & $8.3(2.5-51.8)$ & 0.004 & $5.2(1.5-32.6)$ & 0.03 \\
\hline Sex (Female) & $1.0(0.7-1.4)$ & 0.8 & - & - \\
\hline \multicolumn{5}{|l|}{$\begin{array}{l}\text { Factors associated with } \\
\text { satisfaction of time for } \\
\text { personal/family activities }\end{array}$} \\
\hline Autonomy in my job & $1.6(1.1-2.5)$ & 0.02 & $1.0(0.6-1.6)$ & 0.95 \\
\hline Meaningful work & $1.5(0.9-2.5)$ & 0.1 & - & - \\
\hline $\begin{array}{l}\text { Reasonable amount of clerical } \\
\text { tasks }\end{array}$ & $2.2(1.5-3.3)$ & $<0.001$ & $2.0(1.3-3.2)$ & 0.002 \\
\hline Effective support staff & $1.5(1.003-2.2)$ & 0.049 & $1.2(0.8-2)$ & 0.4 \\
\hline Hours worked a week $(>60)$ & $0.4(0.2-0.7)$ & 0.001 & $0.4(0.2-0.8)$ & 0.02 \\
\hline General hospital & $1.3(0.8-2.1)$ & 0.2 & - & - \\
\hline$>70 \%$ time clinical practice & $2.1(1.4-3.3)$ & $<0.001$ & $1.6(0.96-2.6)$ & 0.07 \\
\hline$>50 \%$ time administrative tasks & $0.4(0.2-0.8)$ & 0.01 & $1(0.5-2)$ & 1 \\
\hline More than $40 \%$ immunology & $1.2(0.8-1.9)$ & 0.4 & - & - \\
\hline Residents & $0.4(0.3-0.6)$ & $<0.001$ & $0.5(0.3-0.9)$ & 0.01 \\
\hline Age $>60$ & $3.1(1.5-6.5)$ & 0.002 & $2.2(0.98-4.9)$ & 0.051 \\
\hline Sex (Female) & $1.1(0.7-1.6)$ & 0.7 & - & - \\
\hline
\end{tabular}




\section{Acknowledgements}

The authors thank the SNFMI and the CEMI members who participated in the study. 


\section{References}

1. West CP, Dyrbye LN, Shanafelt TD. Physician burnout: contributors, consequences and solutions. J Intern Med 2018 doi: 10.1111/joim.12752 [published Online First: Epub Date]|.

2. Shanafelt TD, Hasan O, Dyrbye LN, et al. Changes in Burnout and Satisfaction With Work-Life Balance in Physicians and the General US Working Population Between 2011 and 2014. Mayo Clin Proc 2015;90(12):1600-13 doi: 10.1016/j.mayocp.2015.08.023[published Online First: Epub Date]|.

3. Panagioti M, Geraghty K, Johnson J, et al. Association Between Physician Burnout and Patient Safety, Professionalism, and Patient Satisfaction: A Systematic Review and Meta-analysis. JAMA Intern Med 2018 doi: 10.1001/jamainternmed.2018.3713[published Online First: Epub Date]|.

4. McMahon GT. Managing the Most Precious Resource in Medicine. N Engl J Med 2018;378(16):1552-54 doi: 10.1056/NEJMe1802899[published Online First: Epub Date]|.

5. Krug MF, Golob AL, Wander PL, et al. Changes in Resident Well-Being at One Institution Across a Decade of Progressive Work Hours Limitations. Acad Med 2017;92(10):1480-84 doi: 10.1097/ACM.0000000000001675[published Online First: Epub Date]|.

6. Desai SV, Asch DA, Bellini LM, et al. Education Outcomes in a Duty-Hour Flexibility Trial in Internal Medicine. N Engl J Med 2018;378(16):1494-508 doi: 10.1056/NEJMoa1800965[published Online First: Epub Date]|.

7. Shanafelt TD, Gradishar WJ, Kosty M, et al. Burnout and career satisfaction among US oncologists. J Clin Oncol 2014;32(7):678-86 doi: 10.1200/JC0.2013.51.8480[published Online First: Epub Date]|.

8. Mion G, Journois D, Libert N. Burnout in American Anesthetists, Comparison With a French Cohort. Anesth Analg 2018;126(6):2149 doi: 10.1213/ANE.0000000000002898[published Online First: Epub Date]|.

9. Balayssac D, Pereira B, Virot J, et al. Burnout, associated comorbidities and coping strategies in French community pharmacies-BOP study: A nationwide crosssectional study. PLoS One 2017;12(8):e0182956 doi: 10.1371/journal.pone.0182956[published Online First: Epub Date]|.

10. Banerjee S, Califano R, Corral J, et al. Professional burnout in European young oncologists: results of the European Society for Medical Oncology (ESMO) Young Oncologists Committee Burnout Survey. Ann Oncol 2017;28(7):1590-96 doi: 10.1093/annonc/mdx196[published Online First: Epub Date]|.

11. Shanafelt TD, Boone S, Tan L, et al. Burnout and satisfaction with work-life balance among US physicians relative to the general US population. Arch Intern Med 2012;172(18):1377-85 doi: 10.1001/archinternmed.2012.3199[published Online First: Epub Date]|.

12. Gribben JL, MacLean SA, Pour T, et al. A Cross-sectional Analysis of Compassion Fatigue, Burnout, and Compassion Satisfaction in Pediatric Emergency Medicine Physicians in the United States. Acad Emerg Med 2019 doi: 10.1111/acem.13670[published Online First: Epub Date]|.

13. Williams AW. Addressing Physician Burnout: Nephrologists, How Safe Are We? Clin J Am Soc Nephrol 2018;13(2):325-27 doi: 10.2215/CJN.06800617[published Online First: Epub Date]|. 
14. Panagioti M, Geraghty K, Johnson J. How to prevent burnout in cardiologists? A review of the current evidence, gaps, and future directions. Trends Cardiovasc Med 2018;28(1):1-7 doi: 10.1016/j.tcm.2017.06.018[published Online First: Epub Date]|.

15. Dyrbye LN, Varkey P, Boone SL, et al. Physician satisfaction and burnout at different career stages. Mayo Clin Proc 2013;88(12):1358-67 doi: 10.1016/j.mayocp.2013.07.016[published Online First: Epub Date]|.

16. Shanafelt TD, Raymond M, Kosty M, et al. Satisfaction with work-life balance and the career and retirement plans of US oncologists. J Clin Oncol 2014;32(11):1127-35 doi: 10.1200/JC0.2013.53.4560[published Online First: Epub Date]|.

17. Busis NA, Shanafelt TD, Keran CM, et al. Burnout, career satisfaction, and well-being among US neurologists in 2016. Neurology 2017;88(8):797-808 doi: 10.1212/WNL.0000000000003640[published Online First: Epub Date]|.

18. Maroco J, Campos JA. Defining the student burnout construct: a structural analysis from three burnout inventories. Psychol Rep 2012;111(3):814-30 doi: 10.2466/14.10.20.PR0.111.6.814-830[published Online First: Epub Date]|. 